\title{
A Water Quality Evaluation of Integrated Mangrove Aquaculture System for Water Treatment in Super-Intensive White Leg Shrimp Pond
}

\author{
Mohammad Mahmudi ${ }^{1,2^{*}}$, Muhammad Musa ${ }^{1,2}$, Alamanda Bunga', \\ Nur Azlina Wati', Sulastri Arsad ${ }^{1,2}$, Evellin Dewi Lusiana ${ }^{1,2}$ \\ 1 Department of Aquatic Resources Management, Faculty of Fisheries and Marine Science, Universitas \\ Brawijaya, Veteran Str., Malang 65145, Indonesia \\ 2 AquaRES Research Group, Faculty of Fisheries and Marine Science, Universitas Brawijaya, Veteran Str., Malang \\ 65145 , Indonesia \\ * Corresponding author's e-mail: mudi@ub.ac.id
}

\begin{abstract}
White leg shrimp (Litopenaeus vannamei) is known as a prime aquacultural commodity in Indonesia. However, the rapid growth of shrimp farming has resulted in widespread destruction of coastal ecosystems, including mangrove swamps. Intensification of shrimp culture has led to many other environmental problems. Integration of mangroves into aquaculture systems (IMAS) should be considered as a way to preserve the mangrove ecosystem as well as sustainability of the aquaculture business by treating the influent and effluent water. This study aimed to assess the benefits of integrating mangroves into shrimp aquaculture, in terms of water quality. The results showed that temperature, dissolved oxygen (DO), and nitrite levels in the water significantly differed between sample sites. PCA analysis indicates that total organic matter (TOM), nitrates, nitrites, and ammonia were the principal factors in the overall water quality of the ponds. The highest pollution index was found in the super-intensive shrimp ponds ('moderately polluted'), while the other sites, including the mangrove area, were categorized as 'lightly polluted'. These findings suggest that the presence of mangroves may improve the quality of aquaculture wastewater, but the pollution index may still not reach the 'good' category. It is therefore recommended that a wastewater treatment plant be installed to support the integrated aquaculture system.
\end{abstract}

Keywords: coastal ecosystem; eco-aquaculture; pollution index; principal component.

\section{INTRODUCTION}

White leg shrimp (Litopenaeus vannamei) is a leading aquaculture commodity in Indonesia, and it earns the most foreign currency (besides oil and gas) [Sitompul et al., 2018]. The development of shrimp farming is in line with the high demand for, and price of, shrimp in the international market [Ahmed et al., 2018]. Although shrimp farming provides attractive economic benefits, this activity has received much criticism as a result of its environmental impact [Hamilton, 2013]. The rapid growth of shrimp farming in developing countries such as Indonesia, Vietnam, Bangladesh, and Brazil has resulted in the widespread destruction of mangrove swamps [Ahmed et al., 2018]. The loss of mangroves threatens their ecosystems both ecologically and economically: climate regulation, coastal protection, waste trapping, habitats for various organisms, medicinal raw materials, and tourism are all affected [Kumar et al., 2014].

The intensification of shrimp aquaculture to pursue high production levels produces organic waste, which originates from feed residues and large amounts of shrimp excretions [Barraza-Guardado et al., 2013]. Moreover, super-intensive technology can increase shrimp stocking density from 300 individuals $\mathrm{m}^{2}$ to 1,250 individuals $\mathrm{m}^{2}$ [Wasielesky et al., 2006; Suwoyo et al., 2015]. High stocking density in 
super-intensive aquaculture systems has consequences in terms of waste load that can affect the viability of the shrimp habitat, as well as the aquatic environment in the vicinity of the aquaculture pond [Suwoyo et al., 2015; Musa et al., 2020]. These pollutants can cause eutrophication, decrease dissolved oxygen, and promote the emergence of various diseases [Peng et al., 2009a]. In addition, a decrease in water quality in ponds can result in a shift in the structure of the phytoplankton community, in which it becomes dominated by harmful algae blooms (HAB) [Davidson et al., 2014; Mahmudi et al., 2020b] and shrimp become susceptible to disease [Qiao et al., 2020]. While cultivation technology focuses on increasing productivity and product quality, it should also be able to reduce the negative social and environmental impacts [Rurangwa et al., 2017].

On the other hand, mangrove forest areas have long been used as a waste treatment system to remove or retain $\mathrm{N}$ and $\mathrm{P}$ [Mendoza-Carranza et al., 2010]. The concept of mangroves as biofilters for aquacultural waste emerged as an attempt to overcome the problems of mangrove destruction and unsustainable cultivation practices [Peng et al., 2009a]. This effort is expected to increase the self-purification ability of aquaculture ponds, accelerate the decomposition, transformation, and assimilation of pollutants, reduce the possibility of disease emergence, and increase aquacultural production [Peng et al., 2009a]. The white leg shrimp aquaculture performed at the Brackish and Marine Water Laboratory of Brawijaya University, Probolinggo involves a unique process in which mangroves are used to improve the water quality in its super-intensive ponds: both the water supply for the ponds and aquaculture wastewater pass through a mangrove area [Musa et al., 2021]. This study aimed to assess the benefits of integrating shrimp aquaculture with mangroves, in terms of water quality. Many previous studies have associated the presence of mangroves with physical and chemical improvements in the water quality of intensive aquaculture ponds [Barraza-Guardado et al., 2013; Ahmed et al., 2018]. However, similar research on super-intensive aquaculture is still scarce. This subject is also important because of the economic importance of super-intensive aquaculture, and because of the threats to the coastal environment. Integrating super-intensive aquaculture with mangroves is expected to help prevent the destruction of coastal ecosystems.

\section{MATERIALS AND METHODS}

\section{Study area}

This study was conducted in the Brackish and Marine Water Laboratory of Brawijaya University. This laboratory is situated on the shore of Probolinggo Regency, Indonesia (see Figure 1a), and includes a super-intensive white leg shrimp aquaculture pond. Six sampling sites were selected, as depicted in Figure 1b. Site 1 was the river water near the inlet channel, which is used as the main source of water for filling the intensive pond. Site 2 was a reservoir pond, which functions as a water supply for the other ponds and as an isolation pond to break disease cycles. Sites 3 and 4 were super-intensive ponds. Site 5 was a pond for the disposal of waste from the two aquaculture ponds. Finally, site 6 was the mangrove area.

\section{Materials}

The objects of research in this study were the water samples taken from the six sampling sites described above. Each water sample was observed both in situ and ex situ to measure its water quality. The water quality parameters measured in this study were temperature, transparency, $\mathrm{pH}$, dissolved oxygen, salinity, nitrate, nitrite, ammonia, phosphate, and total organic matter. The instruments used for each parameter are presented in Table 1.

\section{Data analysis}

\section{Statistical analysis}

This study used several statistical techniques, including one-way analysis of variance (ANOVA), the Tukey test and principal component analysis (PCA) (Lusiana \& Mahmudi, 2021) to analyse the variation of water quality parameters in the studied area. Data analysis was performed using the R software (version 3.6.1).

\section{Pollution index}

The pollution index is a measure used to determine the water quality status based on 


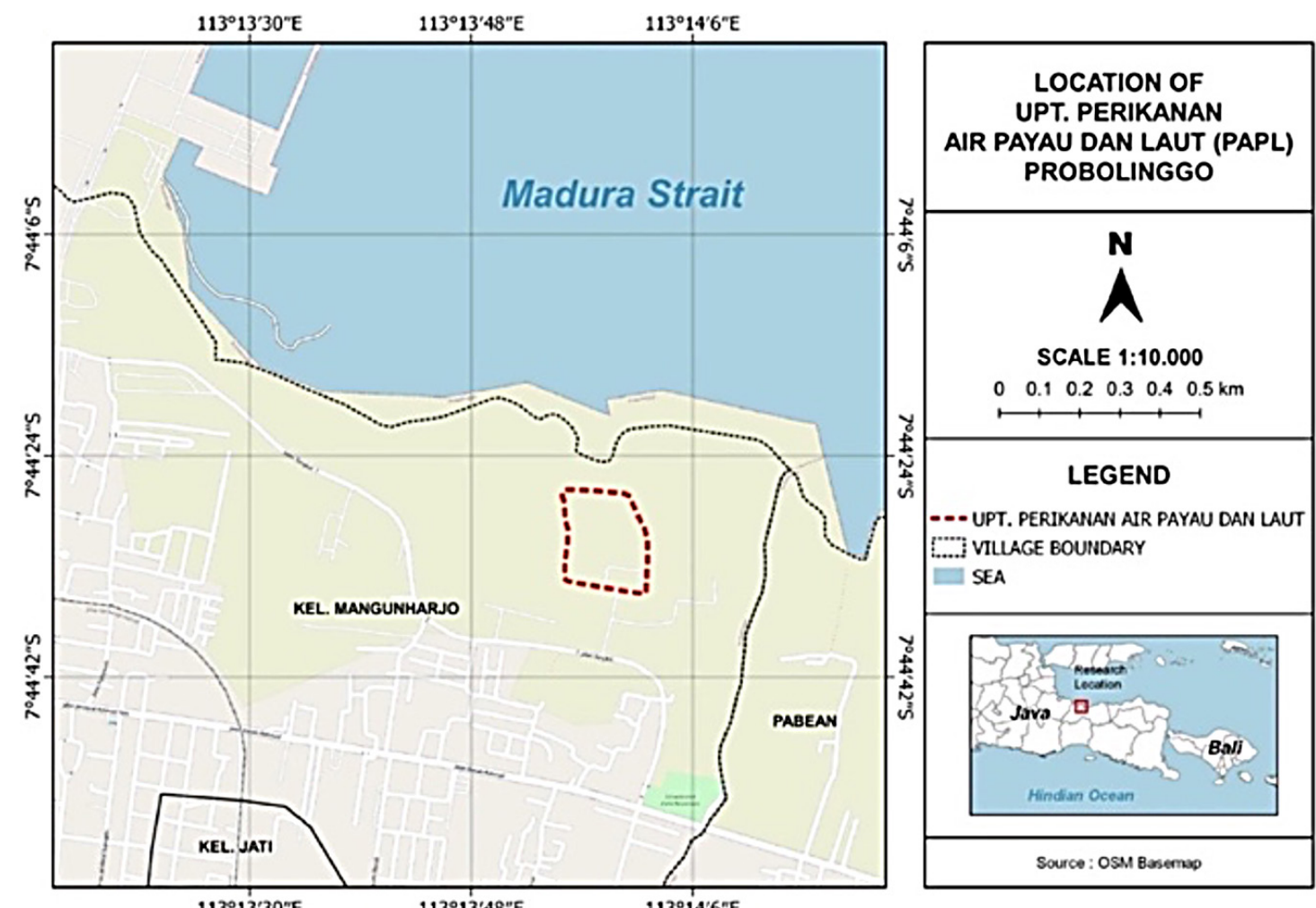

a)

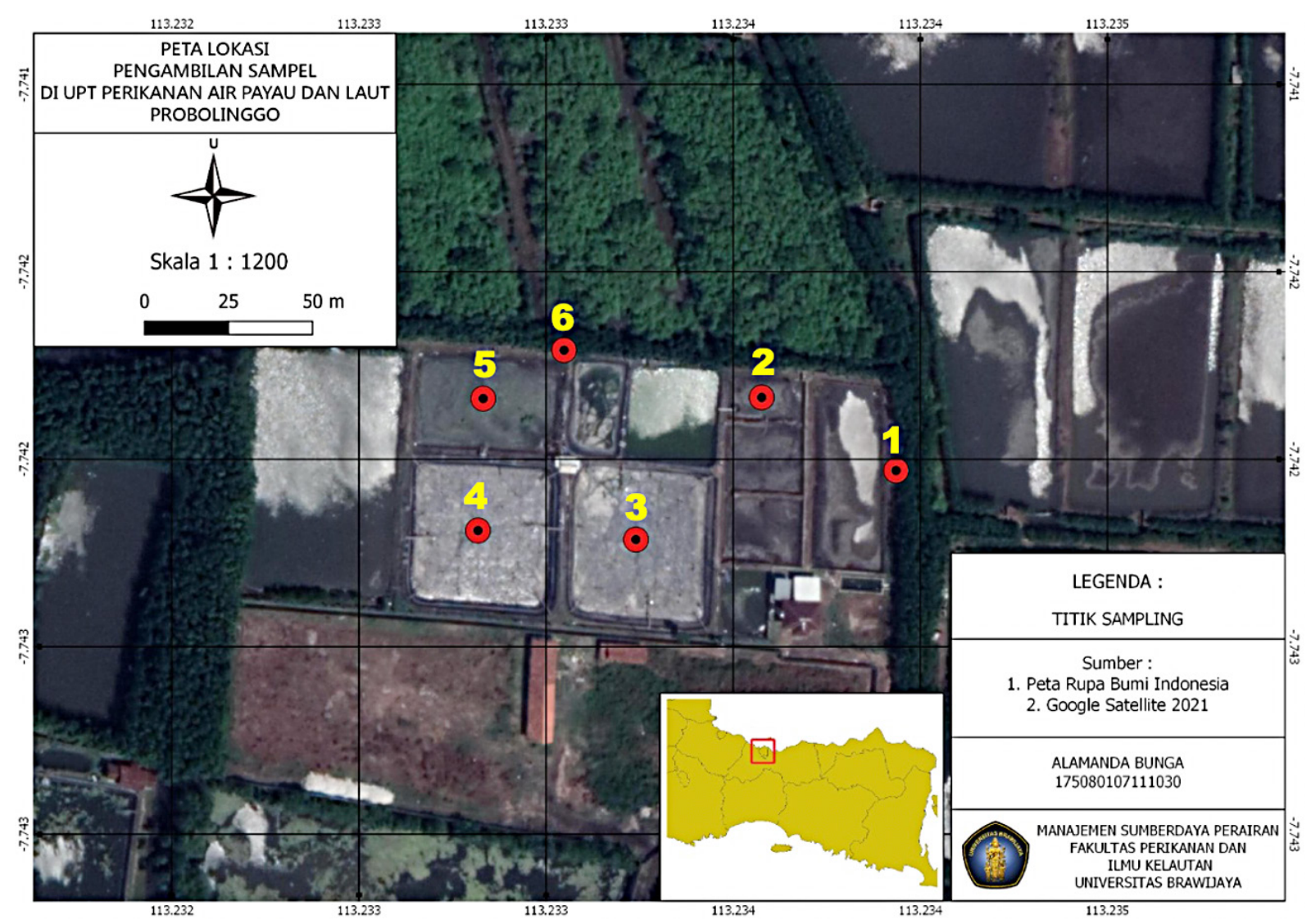

b)

Figure 1. Research location (a) Brackish and Marine Water Laboratory of Brawijaya University, Probolinggo; (b) Sampling sites 
Table 1. Instruments used for water quality parameter measurement

\begin{tabular}{|l|c|l|}
\hline \multicolumn{1}{|c|}{ Parameter } & Unit & \multicolumn{1}{c|}{ Instrument } \\
\hline Temperature & ${ }^{\circ} \mathrm{C}$ & Lutron PDO-520 \\
\hline Transparency & $\mathrm{cm}$ & Secchi Disk \\
\hline $\mathrm{pH}$ & - & Lutron YK-2005WA \\
\hline Salinity & $\mathrm{ppt}$ & Refractometer Atago PAL-06S \\
\hline Dissolved Oxygen (DO) & $\mathrm{mg} / \mathrm{L}$ & Lutron PDO-520 \\
\hline Nitrate $\left(\mathrm{NO}_{3}^{-}\right)$ & $\mathrm{mg} / \mathrm{L}$ & Hanna Instruments HI-3873 Nitrate Test Kit \\
\hline Ammonia $\left(\mathrm{NH}_{3}\right)$ & $\mathrm{mg} / \mathrm{L}$ & Hanna Instruments HI-38049 Ammonia Test Kit \\
\hline Orthophosphate $\left(\mathrm{PO}_{4}\right)$ & $\mathrm{mg} / \mathrm{L}$ & IKM/7.2.30/UPT-LKIL (Colorimetric) \\
\hline Total organic matter (TOM) & $\mathrm{mg} / \mathrm{L}$ & IKM/7.2.44/UPT-LKIL (Titrimetric) \\
\hline
\end{tabular}

pollution levels. The index can be calculated as follows [Darmanto and Sudarmadji, 2013; Tanjung et al., 2019]

$$
I P_{j}=\sqrt{\frac{\left(\frac{C_{i}}{L_{i j}}\right)_{M}^{2}+\left(\frac{C_{i}}{L_{i j}}\right)_{R}^{2}}{2}}
$$

where:

$I P_{j}=$ pollution index for $j$-th purpose

$C_{i}=$ observed $i$-th water quality parameter measurement

$L_{i j}=$ standard of $i$-th water quality parameter for $j$-th purpose

$$
\begin{aligned}
& \left(\frac{C_{i}}{L_{i j}}\right)_{M}=\text { maximum value of ratio } \frac{C_{i}}{L_{i j}} \\
& \left(\frac{C_{i}}{L_{i j}}\right)=\text { mean value of ratio } \frac{C_{i}}{L_{i j}}
\end{aligned}
$$

The water quality status is classified by the PI as follows, according to the decree of the Indonesian Minister of the Environment (decree no. 115, 2003):

$$
\begin{aligned}
& 0<I P_{j}<1: \text { Good } \\
& 1<I P_{j}<5: \text { Lightly polluted }
\end{aligned}
$$

$5<I P_{j}<10$ : Moderately polluted

$I P_{j}>10$ : Heavily polluted

\section{RESULTS AND DISCUSSION}

\section{Water quality measurement results}

The results revealed the variability of minor physico-chemical water quality parameters among the sample sites (Table 2). The temperature, DO, and nitrite levels of the water samples differed significantly between the sample sites ( $p$ $<0.05$, inequal letter notation). On the other hand, transparency, $\mathrm{pH}$, salinity, nitrate, ammonia, orthophosphate, and TOM did not differ significantly between the sample sites ( $p>0.05$, equal letter notation). Higher temperatures were found in the samples from Site 5, and these exceeded the maximum values set by national standards. Average $\mathrm{pH}$ values were lower than 6 , which is the minimum $\mathrm{pH}$ set by national standards for class III or

\begin{tabular}{|c|c|c|c|c|c|c|c|c|c|c|}
\hline Site & Temperature & Transparency & $\mathrm{pH}$ & DO & Salinity & Nitrate & Nitrite & Ammonia & $\begin{array}{l}\text { Orthophos- } \\
\text { phate }\end{array}$ & TOM \\
\hline 1 & $\begin{array}{l}30.34 \pm \\
2.088^{\mathrm{ab}}\end{array}$ & $\begin{array}{l}35.25 \pm \\
3.304^{a}\end{array}$ & $5.45 \pm 0.430^{a}$ & $7.37 \pm 0.203^{a}$ & $\begin{array}{c}25.75 \pm \\
3.304^{\mathrm{a}}\end{array}$ & $\begin{array}{l}6.75 \pm \\
1.500^{a}\end{array}$ & $\begin{array}{l}0.17 \pm \\
0.022^{b}\end{array}$ & $\begin{array}{l}1.25 \pm \\
0.370^{\mathrm{a}}\end{array}$ & $0.27 \pm 0.135^{a}$ & $\begin{array}{l}87.06 \pm \\
44.57^{a}\end{array}$ \\
\hline 2 & $\begin{array}{l}31.35 \pm \\
1.698 \text { ab }\end{array}$ & $\begin{array}{l}24.63 \pm \\
11.814^{a}\end{array}$ & $5.35 \pm 0.275^{\mathrm{a}}$ & $6.96 \pm 0.441^{\mathrm{b}}$ & $\begin{array}{c}26 \pm \\
2.160^{\text {a }}\end{array}$ & $\begin{array}{l}5.50 \pm \\
1.732^{a}\end{array}$ & $\begin{array}{l}0.17 \pm \\
0.013^{b}\end{array}$ & $\begin{array}{l}1.55 \pm \\
0.058^{a}\end{array}$ & $0.26 \pm 108.39^{a}$ & $\begin{array}{l}80.66 \pm \\
32.54^{a}\end{array}$ \\
\hline 3 & $\begin{array}{l}29.40 \pm \\
0.752^{b}\end{array}$ & $\begin{array}{l}26.88 \pm \\
7.923^{a}\end{array}$ & $5.50 \pm 0.388^{a}$ & $7.15 \pm 0.099^{b}$ & $\begin{array}{l}23.75 \pm \\
0.957^{\mathrm{a}}\end{array}$ & $\begin{array}{l}16.50 \pm \\
10.34^{\mathrm{a}}\end{array}$ & $\begin{array}{l}1.05 \pm \\
0.614^{\mathrm{a}}\end{array}$ & $\begin{array}{l}2.38 \pm \\
0.850^{a}\end{array}$ & $0.34 \pm 0.176^{a}$ & $\begin{array}{c}117.63 \pm \\
80.58^{a}\end{array}$ \\
\hline 4 & $\begin{array}{l}29.63 \pm \\
0.567^{\mathrm{b}}\end{array}$ & $\begin{array}{l}28.81 \pm \\
5.684^{a}\end{array}$ & $5.27 \pm 0.343^{a}$ & $6.76 \pm 0.125^{b}$ & $\begin{array}{l}22.25 \pm \\
0.500^{a}\end{array}$ & $\begin{array}{l}15.0 \pm \\
10.36^{a}\end{array}$ & $\begin{array}{c}0.95 \pm \\
0.663^{\mathrm{ab}}\end{array}$ & $\begin{array}{l}2.43 \pm \\
0.847^{\mathrm{a}}\end{array}$ & $0.74 \pm 0.558^{a}$ & $\begin{array}{l}120.4 \pm \\
65.11^{\mathrm{a}}\end{array}$ \\
\hline 5 & $\begin{array}{l}33.05 \pm \\
2.104^{a}\end{array}$ & $\begin{array}{l}20.38 \pm \\
9.928^{a}\end{array}$ & $5.44 \pm 0.159^{a}$ & $3.89 \pm 2445^{c}$ & $\begin{array}{c}23 \pm \\
2.160^{\mathrm{a}}\end{array}$ & $\begin{array}{c}8.0 \pm \\
4.690^{a}\end{array}$ & $\begin{array}{l}0.19 \pm \\
0.019^{b}\end{array}$ & $\begin{array}{l}1.55 \pm \\
0.173^{a}\end{array}$ & $0.77 \pm 1.053^{a}$ & $\begin{array}{l}92.04 \pm \\
38.67^{a}\end{array}$ \\
\hline 6 & $\begin{array}{l}30.78 \pm \\
1.132^{\mathrm{ab}}\end{array}$ & $\begin{array}{c}30.00 \pm \\
11.58^{a}\end{array}$ & $5.32 \pm 1.5414^{a}$ & $5.68 \pm 0.110^{\mathrm{bc}}$ & $\begin{array}{l}24.75 \pm \\
2.630^{a}\end{array}$ & $\begin{array}{l}6.75 \pm \\
2.217^{a}\end{array}$ & $\begin{array}{l}0.19 \pm \\
0.013^{b}\end{array}$ & $\begin{array}{l}1.43 \pm \\
0.310^{a}\end{array}$ & $0.29 \pm 0.118^{a}$ & $\begin{array}{l}114.0 \pm \\
82.10^{a}\end{array}$ \\
\hline Unit & ${ }^{\circ} \mathrm{C}$ & $\mathrm{cm}$ & - & $\mathrm{mg} / \mathrm{L}$ & ppt & $\mathrm{mg} / \mathrm{L}$ & $\mathrm{mg} / \mathrm{L}$ & $\mathrm{mg} / \mathrm{L}$ & $\mathrm{mg} / \mathrm{L}$ & $\mathrm{mg} / \mathrm{L}$ \\
\hline $\begin{array}{l}\text { Stan- } \\
\text { dards }\end{array}$ & 28-32 & $20-40$ & $6-9$ & $>3$ & $26-32$ & $<20$ & $<0.06$ & $<0.5$ & $0.10-5.0$ & $<90$ \\
\hline
\end{tabular}
fishery purposes. Similarly, the salinity levels at all sample sites were also below the lower limit of the standard set for class III water quality (27-32

Table 2. Physicochemical water quality measurement results 
ppt). Meanwhile, the concentration of nitrite, ammonia, and TOM exceeded the water quality standard, which sets maximum limits at $0.06 \mathrm{mg} / \mathrm{L}$, $0.5 \mathrm{mg} / \mathrm{L}$, and $90 \mathrm{mg} / \mathrm{L}$, respectively. A notably high level of these compounds was found in Sites 3 and 4, the super-intensive aquaculture ponds.

\section{Principal component analysis on water quality}

Ten parameters (temperature, transparency, $\mathrm{pH}$, DO, salinity, nitrate, ammonia, phosphate, and TOM) were selected as the input for principal component analysis, as shown in Figure 2. The eigenvalues greater than 1.0 were deemed to be significant. The PCA identified four major components which explained $82.652 \%$ of total water quality change. TOM $(0.614)$, nitrate $(0.884)$, nitrite (0.910), and ammonia (0.900) were all high and were selected in the first principal component (component 1). Meanwhile, the second principal component (component 2) returned high results for transparency (0.595), salinity $(0.731)$, and $\mathrm{pH}$ $(-0.616)$. The weighting for TOM, nitrate, nitrite, ammonia, transparency, salinity, and $\mathrm{pH}$ was also greater than it was for the other parameters.

\section{Pollution index of super-intensive white leg shrimp pond and its adjacent waters}

According to the results of the pollution index calculation shown in Figure 3, all sample sites were characterized by the conditions of light to moderate pollution. At the beginning of the first sampling period, the pollution index was constant at all sites, which were categorized as "lightly polluted' (PI $<5$ ). However, during the third and fourth sampling periods, the pollution indices at the super-intensive ponds increased to more than 5 , and the super-intensive ponds were thus categorized as 'moderately polluted'. In contrast, the pollution indices of the other sites remained stable over the research period.

\section{DISCUSSION}

Rapid development of shrimp aquaculture in coastal ecosystems may destroy mangrove swamps [Hamilton, 2013] and reduce the sustainability of the aquaculture ventures themselves [Sampantamit et al., 2020]. To maintain the mangrove ecosystem, economic benefits, and longterm shrimp production, the integration of mangroves into the aquaculture processes should be considered [Peng et al., 2009b]. Previous studies have suggested that mangroves can play a role as waste traps, and may thus improve the quality of wastewater as well as prevent pollution [Yang et al., 2008; Mahmood et al., 2013]. Passing the water supply and the wastewater disposal of the shrimp aquaculture plant at the Brackish and Marine Water Laboratory through an area of mangroves is expected to improve the water quality at the plant [Musa et al., 2020]. Because successful aquaculture practice relies on good water quality, the monitoring and assessment of water quality in

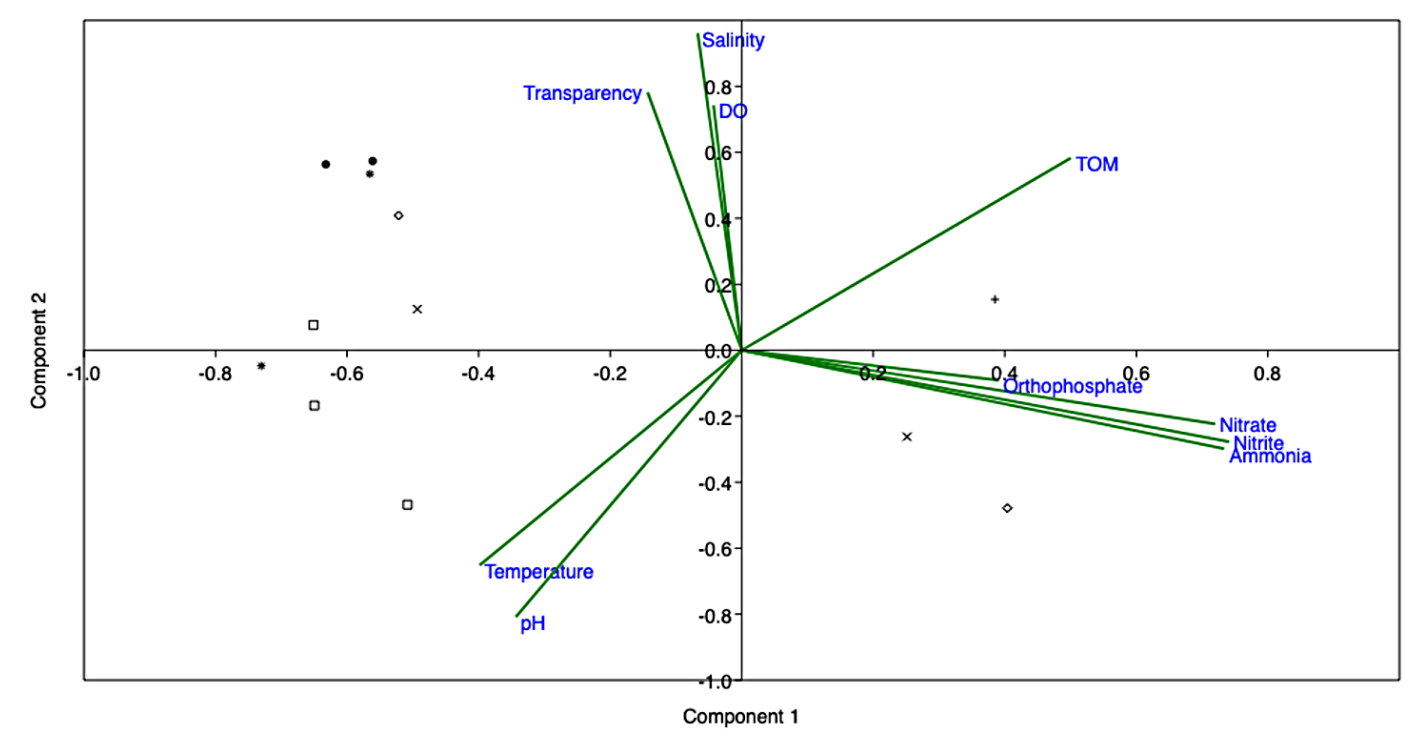

Figure 2. Biplot of principal component analysis on water quality parameter 
aquaculture ponds and their adjacent waters is critical [Naylor et al., 2021]. In shrimp aquaculture, water temperature greatly affects the oxygen consumption as well as the growth and survival rates of the biota [Guan et al., 2003; Bastos et al., 2018]. The temperature levels that did not conform to national standards were observed at site 5 , the sewage pond, which contains no aquacultural biota, but temperature levels were lower in the mangrove area used for wastewater disposal (site 6). Therefore, the variability of this parameter was irrelevant to water quality monitoring in this study area; this is supported by the PCA result (see figure 3).

Transparency is also a very important parameter, because it is closely related to the photosynthetic activity and primary production in the ponds [Abdel-Raouf et al., 2012]. Water transparency is determined by turbidity, suspended solids and weather conditions [Liu et al., 2020]. The PCA result suggested that transparency was one of the dominant parameters in the water quality assessment. Even though there was no significant difference in transparency across sites, nonsignificantly higher levels of transparency were measured at sites 1 and 6 . This implies that the unique properties of the mangrove root system can trap particles and sediment [Kida and Fujitake, 2020]. The presence of aquacultural residues can cause water to become more acidic or more alkaline [Marimuthu et al., 2019]. In this research, the $\mathrm{pH}$ values measured were less than 6 , a level of acidity which can be deadly to aquatic organisms [Velma et al., 2009] and thus needs to be managed carefully. The addition of sodium bicarbonate to the water can help to increase $\mathrm{pH}$ for shrimp aquaculture [Zhang et al., 2017].

The level of salinity in this research was lower than $27 \mathrm{ppt}$, which is the minimum set by national standards for class III waters. However, a prior study has indicated that low salinity does not appear to alter osmotic regulation to the point where the growth and survival rates in Litopenaeus vannamei would be affected [Zhang et al., 2017]. If the acclimation procedure is performed correctly, the species has high potential in inland saline waters with salinities as low as 1 ppt [Allen, 2004]. DO also plays an essential part in aquaculture production [Boyd, 2003; Rahman et al., 2020]. In fisheries in general, the DO levels of 4 to $5 \mathrm{mg} / \mathrm{L}$ or more are considered optimal [Boyd, 2017]. Generally, the levels below $2.0 \mathrm{mg} / \mathrm{L}$ are linked to impaired growth and a significant risk of mortality [Ferreira et al., 2011]. In this study, all DO concentrations followed the guidelines for intensive aquaculture [Cheng et al., 2003] as well as quality standards for coastal waters [Siringoringo et al., 2018]. In intensive shrimp aquaculture, commercial feed is usually used because the farmers are forced to feed their shrimp according to a specific growth plan as a result of short harvest times [Dauda et al., 2019]. Excessive feed waste will result in high organic waste and increase the TOM level in ponds [Turcios and Papenbrock, 2014]. The levels of TOM at all sampling sites were remarkably high, and surpassed water quality standards.

As organic matter increases, the nutrient concentration in the water increases as well (Lusiana et al., 2020). Nitrogen and phosphate are

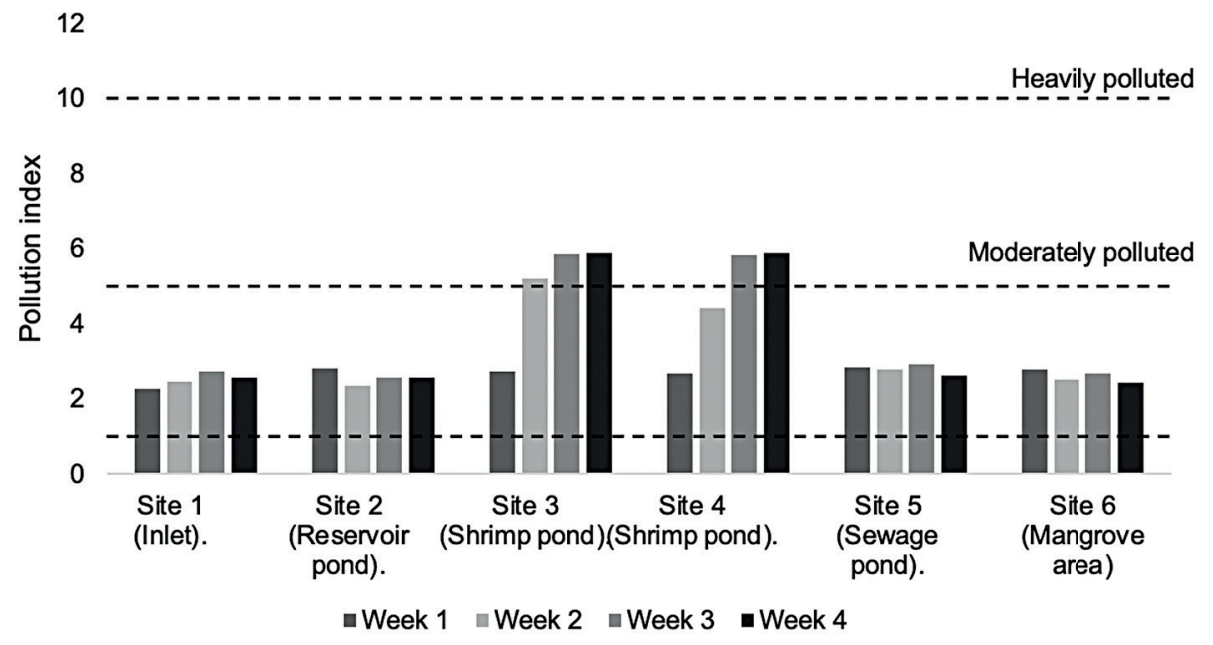

Figure 3. Water pollution index of super intensive white leg shrimp pond and its adjacent waters 
commonly employed as eutrophication indices, and have been shown to be positively associated with phytoplankton abundance (Lv et al., 2011; Mahmudi et al., 2020). Phosphate exists in various forms, but only orthophosphate can be utilized directly by microorganisms in water (Lusiana et al., 2019; Mahmudi et al., 2019). The concentrations of orthophosphate in the samples were quite low compared to the maximum of $5 \mathrm{mg} / \mathrm{L}$ set by the national standard for water quality [Lusiana et al., 2020]. Because natural food production is limited in the intensive pond system, the nitrogen and phosphate levels are increased by the use of commercial feed [Dauda et al., 2019]. Among the three forms of nitrogen considered in this research, the nitrite and ammonia levels were found to exceed the water quality standards for fisheries. High levels of ammonia in water can damage the gills, affect the growth and moulting rate of shrimp, as well as reduce the ability of the blood to carry oxygen [Shaari et al., 2011]. If the conversion of ammonia to nitrate is inhibited, then nitrite will be concentrated in large quantities and will result in a decrease in the shrimps' immunity, so that they become more susceptible to infection by vibrio virus [Tseng and Chen, 2004; Widanarni et al., 2020].

The PCA, as a classic multivariate analysis approach, can identify and minimize the variables responsible for changes in water quality by decreasing the dimensions of large-scale datasets [Jolliffe and Cadima, 2016]. Previous research obtained a variety of principal components: frequently between three and six principal components [Banda and Kumarasamy, 2020; Yang et al., 2020]. The PCA in this study extracted four principal components which explained $82.652 \%$ of the total variation in water quality. TOM, nitrate, nitrite, and ammonia had high loading and were selected in the first principal component. These parameters are fundamental environmental variables in shrimp aquaculture [Llario et al., 2019; Xu et al., 2020]. Meanwhile, transparency, salinity, and $\mathrm{pH}$ had high loading and were selected in the second principal component. These parameters are regarded as common indicators of water quality, not only in aquaculture ponds, but also in coastal waters more generally [Montaño and Robadue, 1995]. The pollution index at the inlet (site 1) was categorized as 'lightly polluted', as were the reservoir ponds, sewage ponds, and mangrove areas. Their condition was particularly influenced by the nitrite and ammonia parameters, which exceeded the specified water quality standards [Ministry of Environment, 2001]. On the other hand, the super-intensive ponds had the highest pollution index values (categorized as 'moderately polluted'). The high pollution indices of sites 3 and 4 are due to the fact that these sites are shrimp-rearing ponds, which contain a build-up of organic materials in the form of leftover feed, shrimp faeces and dead plankton [Musa et al., 2020]. Shrimp feed is one of the sources of organic matter which disturbs the stability of the pond water environment: it is easily soluble, settles, and undergoes decay at the bottom of the water [Widanarni et al., 2010; Hidayat, 2017]. The Brackish and Marine Water Laboratory uses a super-intensive system, and the more intensive the cultivation system is, the more feed inputs are given and the higher the abundance of biota [Anras et al., 2010]. This affects the amounts of metabolic waste and leftover shrimp feed deposited in pond waters [Attasat et al., 2013]. Artificial feeding in ponds can change the conditions of nitrogen compounds in the water [Dauda et al., 2019].

The pollution index in the waste pond (site 5) was lower than in the super-intensive ponds. This was due to dilution by influent estuary water, as the divider door in this waste pond was open during measurement. The low pollution index in the mangrove area was due to the absorption of organic matter by the mangroves. Sedimentation in waste ponds and the accumulation of organic matter by mangrove plants causes reduction of the excess organic matter content in the water [Bao et al., 2013; Hossain and Nuruddin, 2016]. The Brackish and Marine Water Laboratory uses the eco-aquaculture irrigation system, which utilizes pond cultivation waste by passing wastewater through the mangrove area, then re-using it as a water source for the intensive ponds. Because of the mangrove area, the waste that has been produced by shrimp farming can thus be partially re-used as a source of water for aquaculture production. It is important to note that the water supply for shrimp farming is derived not only from treated wastewater, but also from tidal and estuary water. These three sources result in good water quality due to the dilution of the wastewater by sea and estuary water.

\section{CONCLUSIONS}

The intensification of shrimp aquaculture has led to many environmental problems and raised the questions about the sustainability of this activity. The integration of shrimp aquaculture with mangroves has the potential to overcome these 
issues. The results of this study suggest that temperature, DO, and nitrite levels in the water differed significantly between sample sites, while transparency, $\mathrm{pH}$, salinity, nitrate, ammonia, orthophosphate, and TOM did not. However, PCA analysis indicates that transparency is one of the principal factors affecting the general water quality of the ponds. The highest pollution index was found in the intensive shrimp-rearing ponds (Sites 5 and 6), which were categorized as moderately polluted. Meanwhile, the other sites, including the mangrove area, were categorized as lightly polluted. This finding suggests that the presence of mangroves could improve the water quality of aquaculture wastewater, but that the pollution index still did not reach the 'good' category. It is therefore recommended that a wastewater treatment plant should be installed to support the integrated aquaculture system.

\section{Acknowledgements}

This research was funded by Doctor Associate professor Researcher Grant (Hibah Doktor Lektor Kepala) 2021 Number: 2105/UN10.F06/ PP/2021 Faculty of Fisheries and Marine Science, Universitas Brawijaya.

\section{REFERENCES}

1. Abdel-Raouf N., Al-Homaidan A.A., Ibraheem I.B.M. 2012. Microalgae and wastewater treatment. Saudi Journal of Biological Sciences, 19(3), 257-275.

2. Ahmed N., Thompson S., Glaser M. 2018. Integrated mangrove-shrimp cultivation: Potential for blue carbon sequestration. Ambio, 47(4), 441-452.

3. Allen D. 2004. Acclimating Pacific White Shrimp, Litopenaeus vannamei, to Inland, Low-Salinity Waters.

4. Anras L., Boglione C., Cataudella S., Dinis M.T., Livi S., Makridis P., Marino G., Ramalho A., Yúfera M. 2010. The current status of extensive and semiintensive aquaculture practices in Southern Europe. Aquaculture Europe, 35(2), 12-16.

5. Attasat S., Wanichpongpan P., Ruenglertpanyakul W. 2013. Design of Integrated Aquaculture of the Pacific White Shrimp, Tilapia and Green Seaweed. Journal of Sustainable Energy \& Environment, 4, 9-14.

6. Banda T.D., Kumarasamy M. 2020. Application of multivariate statistical analysis in the development of a surrogate water quality index (WQI) for South African watersheds. Water (Switzerland), 12(6).

7. Bao H., Wu Y., Unger D., Du J., Herbeck L.S., Zhang J. 2013. Impact of the conversion of mangroves into aquaculture ponds on the sedimentary organic matter composition in a tidal flat estuary (Hainan Island, China). Continental Shelf Research, 57, 82-91.

8. Barraza-Guardado R.H., Arreola-Lizárraga J.A., López-Torres M.A., Casillas-Hernández R., Miranda-Baeza A., Magallón-Barrajas F., Ibarra-Gámez C. 2013. Effluents of Shrimp Farms and Its Influence on the Coastal Ecosystems of Bahía de Kino, Mexico. The Scientific World Journal, 2013, 306370.

9. Bastos A.M., Lima J.F., Tavares-dias M. 2018. Aquatic Living Resources Effect of increase in temperature on the survival and growth of Macrobrachium amazonicum ( Palaemonidae ) in the Amazon. Aquatic Living Resources, 31(21), 1-6.

10. Boyd C.E. 2003. Guidelines for aquaculture effluent management at the farm-level. Aquaculture, 226(1), 101-112.

11. Boyd C.E. 2017. Chapter 6 - General Relationship Between Water Quality and Aquaculture Performance in Ponds. In: Jeney, G.B.T.-F.D. (Ed.),. Academic Press, 147-166.

12. Cheng W., Liu C.-H., Kuo C.-M. 2003. Effects of dissolved oxygen on hemolymph parameters of freshwater giant prawn, Macrobrachium rosenbergii (de Man). Aquaculture, 220(1), 843-856.

13. Darmanto D., Sudarmadji. 2013. Pengelolaan sungai berbasis masyarakat lokal di Daerah Lereng Selatan Gunungapi Merapi. Jurnal Manusia dan Lingkungan, 20(2), 229-239.

14. Dauda A.B., Ajadi A., Tola-Fabunmi A.S., Akinwole A.O. 2019. Waste production in aquaculture: Sources, components and managements in different culture systems. Aquaculture and Fisheries, 4(3), 81-88.

15. Davidson K., Gowen R.J., Harrison P.J., Fleming L.E., Hoagland P., Moschonas G. 2014. Anthropogenic nutrients and harmful algae in coastal waters. Journal of Environmental Management, 146, 206-216.

16. Ferreira N.C., Bonetti C., Seiffert W.Q. 2011. Hydrological and Water Quality Indices as management tools in marine shrimp culture. Aquaculture, 318(3), 425-433.

17. Guan Y., Yu Z., Li C. 2003. The effects of temperature on white spot syndrome infections in Marsupenaeus japonicus. Journal of Invertebrate Pathology, 83(3), 257-260.

18. Hamilton S. 2013. Assessing the role of commercial aquaculture in displacing mangrove forest. Bulletin of Marine Science, 89(2), 585-601.

19. Hidayat R. 2017. Efisiensi pemanfaatan pakan dan pertumbuhan udang windu (Penaeus monodon) pada media bioflok dengan $\mathrm{C} / \mathrm{N}$ ratio berbeda. Jurnal Sains Teknologi Akuakultur. 1(1), 11-20.

20. Hossain M.D., Nuruddin A.A. 2016. Soil and mangrove: A review. Journal of Environmental Science and Technology, 9(2), 198-207. 
21. Jolliffe I.T., Cadima J. 2016. Principal component analysis: a review and recent developments. Philosophical transactions. Series A, Mathematical, physical, and engineering sciences, 374(2065), 20150202.

22. Kida M., Fujitake N. 2020. Organic carbon stabilization mechanisms in mangrove soils: A review. Forests, 11(9), 1-15.

23. Kumar J., Angad G., Veterinary D., Sagar M.V, Naik K.A.S., Animal K.V., Pal J., Animal K.V. 2014. Ecological Benefits of Mangrove. An International Research Journal, 48(February), 85-88.

24. Liu D., Duan H., Loiselle S., Hu C., Zhang G., Li J., Yang H., Thompson J.R., Cao Z., Shen M., Ma R., Zhang M., Han W. 2020. Observations of water transparency in China's lakes from space. International Journal of Applied Earth Observation and Geoinformation, 92, 102187.

25. Llario F., Falco S., Sebastiá-Frasquet M.-T., Escrivá J., Rodilla M., Poersch L.H. 2019. The Role of Bacillus amyloliquefaciens on Litopenaeus vannamei During the Maturation of a Biofloc System. Journal of Marine Science and Engineering.

26. Lusiana E., Mahmudi M. 2021. ANOVA untuk Penelitian Eksperimen: Teori dan Praktik dengan R. UB Press, Malang.

27. Lusiana E.D., Arsad S., Kusriani, Buwono N.R., Putri I.R. 2019. Performance of Bayesian quantile regression and its application to eutrophication modelling in Sutami Reservoir, East Java, Indonesia. Ecological Questions, 30(2), 69-77.

28. Lusiana E.D., Buwono N.R., Mahmudi M., Noviasari P.P. 2020. Nutrient limit estimation for eutrophication modelling at Sengguruh Reservoir, Malang, Indonesia. Nature Environment and Pollution Technology, 19(1), 361-365.

29. Lv J., Wu H., Chen M. 2011. Effects of nitrogen and phosphorus on phytoplankton composition and biomass in 15 subtropical, urban shallow lakes in Wuhan, China. Limnologica, 41(1), 48-56.

30. Mahmood Q., Pervez A., Zeb B.S., Zaffar H., Yaqoob H., Waseem M., Zahidullah, Afsheen S. 2013. Natural treatment systems as sustainable ecotechnologies for the developing countries. BioMed Research International, 2013.

31. Mahmudi M., Lusiana E.D., Arsad S., Buwono N.R., Darmawan A., Nisya T.W., Gurinda G.A. 2019. A study on phosphorus-based carrying capacity and trophic status index of floating net cages area in Ranu Grati, Indonesia. AACL Bioflux, 12(5), 1902-1908.

32. Mahmudi M., Lusiana E.D., Herawati E.Y., Serihollo L.G. 2020a. Environmental factors and seasonal effect on the potential harmful algae presence at Ambon Bay, Indonesia. Biodiversitas Journal of Biological Diversity, 21(7), 3101-3107.

33. Mahmudi M., Serihollo L.G., Herawati E.Y.,
Lusiana E.D., Buwono N.R. 2020b. A count model approach on the occurrences of harmful algal blooms (HABs) in Ambon Bay. Egyptian Journal of Aquatic Research, 46(4), 347-353.

34. Marimuthu K., Palaniandya H., Muchlisin Z.A. 2019. Effect of different water $\mathrm{pH}$ on hatching and survival rates of African catfish Clarias gariepinus (Pisces: Clariidae). Aceh Journal of Animal Science, 4(2), 80-88.

35. Mendoza-Carranza M., Hoeinghaus D.J., Garcia A.M., Romero-Rodriguez Á. 2010. Aquatic food webs in mangrove and seagrass habitats of Centla Wetland, a Biosphere reserve in Southeastern Mexico. Neotropical Ichthyology, 8(1), 171-178.

36. Ministry of Environment. 2001. Peraturan Pemerintah Republik Indonesia Tentang Pengelolaan Kualitas Air Dan Pengendalian Pencemaran Air. Indonesia.

37. Montaño M., Robadue D. 1995. Coastal Water Quality Monitoring and Management. Coastal Resources Center, University of Rhode Island.

38. Musa M., Arsad S., Mahmudi M., Lusiana E., Agharid N., Darmayanti S., Prasetiya F. 2021. Does Water Quality Affect the Plankton Dynamics and the Specific Growth Rate of Litopenaeus vannamei? Polish Journal of Environmental Studies, 30(5), 1-11.

39. Musa M., Lusiana E.D., Buwono N.R., Arsad S., Mahmudi M. 2020. The effectiveness of silvofishery system in water treatment in intensive whiteleg shrimp (Litopenaeus vannamei) ponds, probolinggo district, East Java, Indonesia. Biodiversitas, 21(10), 4695-4701.

40. Naylor R.L., Hardy R.W., Buschmann A.H., Bush S.R., Cao L., Klinger D.H., Little D.C., Lubchenco J., Shumway S.E., Troell M. 2021. A 20-year retrospective review of global aquaculture. Nature, 591(7851), 551-563.

41. Peng Yisheng Li, X., Wu K., Peng Yougui Chen G. 2009a. Effect of an integrated mangrove-aquaculture system on aquacultural health. Frontiers of Biology in China, 4(4), 579.

42. Peng Yisheng Li X., Wu K., Peng Yougui Chen G. 2009b. Effect of an integrated mangrove-aquaculture system on aquacultural health. Frontiers of Biology in China, 4(4), 579-584.

43. Qiao L., Chang Z., Li J., Chen Z. 2020. Phytoplankton community succession in relation to water quality changes in the indoor industrial aquaculture system for Litopenaeus vannamei. Aquaculture, 527(April), 735441.

44. Rahman A., Dabrowski J., McCulloch J. 2020. Dissolved oxygen prediction in prawn ponds from a group of one step predictors. Information Processing in Agriculture, 7(2), 307-317.

45. Rurangwa E., Baumgartner U., Nguyen H.M., van de Vis J.W. 2017. Aquaculture Innovation in Vietnam. Journal of Environmental Science and Engineering B, 6(4), 236-241. 
46. Sampantamit T., Ho L., Lachat C., Sutummawong N., Sorgeloos P., Goethals P. 2020. Aquaculture production and its environmental sustainability in Thailand: Challenges and potential solutions. Sustainability (Switzerland), 12(5), 1-17.

47. Shaari A.L., Surif M., Latiff F.A., Omar W.M.W., Ahmad M.N. 2011. Monitoring of Water Quality and Microalgae Species Composition of Penaeus monodon Ponds in Pulau Pinang, Malaysia. Tropical life sciences research, 22(1), 51-69.

48. Siringoringo H.H., Narendra B.H., Salim A.G. 2018. Water Quality of Mangrove at Ciasem, Pamanukan, Subang District, West Java. Journal of Natural Resources and Environmental Management, 8(3), 301-307.

49. Sitompul T.K., Sahara S., Anggraeni L. 2018. The Effects of Trade Facilitation on Indonesian Fisheries Export. Jurnal Manajemen dan Agribisnis, 15(3), 230-238.

50. Suwoyo H.S., Nirmala K., Djokosetiyanto Mulyaningrum S.R.H. 2015. Faktor Dominan yang Berpengaruh Pada TIingkat Konsumsi Oksigen Sedimen Di Tambak IntensifUdang Vaname(Litopenaeus vannamei). Jurnal Ilmu dan Teknologi Kelautan Tropis, 7(2), 639-654.

51. Tanjung R.H.R., Hamuna B., Alianto. 2019. Assessment of water quality and pollution index in coastal waters of Mimika, Indonesia. Journal of Ecological Engineering, 20(2), 87-94.

52. Tseng I.-T., Chen J.-C. 2004. The immune response of white shrimp Litopenaeus vannamei and its susceptibility to Vibrio alginolyticus under nitrite stress. Fish \& Shellfish Immunology, 17(4), 325-333.

53. Turcios A.E., Papenbrock J. 2014. Sustainable Treatment of Aquaculture Effluents-What Can We Learn from the Past for the Future. Sustainability, 836-856.

54. Velma V., Vutukuru S.S., Tchounwou P.B. 2009. Ecotoxicology of hexavalent chromium in freshwater fish: a critical review. Reviews on environmental health, 24(2), 129-145.
55. Wasielesky W., Atwood H., Stokes A., Browdy C.L. 2006. Effect of natural production in a zero exchange suspended microbial floc based super-intensive culture system for white shrimp Litopenaeus vannamei. Aquaculture, 258(1-4), 396-403.

56. Widanarni W., Rahmi D., Gustilatov M., Sukenda S., Utami D.A.S. 2020. Immune responses and resistance of white shrimp (Litopenaeus vannamei) fed Probiotic Bacillus sp NP5 and prebiotic honey against White Spot Syndrome Virus infection. Jurnal Akuakultur Indonesia, 19(2), 118-130.

57. Widanarni Yuniasari D., Sukenda Ekasari J. 2010. Nursery Culture Performance of Litopenaeus vannamei with Probiotics Addition and Different $\mathrm{C} / \mathrm{N}$ Ratio Under Laboratory Condition. HAYATI Journal of Biosciences, 17(3), 115-119.

58. Xu W., Xu Y., Su H., Hu X., Yang K., Wen G., Cao Y. 2020. Characteristics of Ammonia Removal and Nitrifying Microbial Communities in a Hybrid Biofloc-RAS for Intensive Litopenaeus vannamei Culture: A Pilot-Scale Study. Water.

59. Yang Q., Tam N.F.Y., Wong Y.S., Luan T.G., Su W.S., Lan C.Y., Shin P.K.S., Cheung S.G. 2008. Potential use of mangroves as constructed wetland for municipal sewage treatment in Futian, Shenzhen, China. Marine Pollution Bulletin, 57(6), 735-743.

60. Yang W., Zhao Y., Wang D., Wu H., Lin A., He L. 2020. Using principal components analysis and idw interpolation to determine spatial and temporal changes of Surfacewater quality of Xin' Anjiang river in huangshan, china. International Journal of Environmental Research and Public Health, 17(8), 1-14.

61. Zhang K., Pan L., Chen W., Wang C. 2017. Effect of using sodium bicarbonate to adjust the $\mathrm{pH}$ to different levels on water quality, the growth and the immune response of shrimp Litopenaeus vannamei reared in zero-water exchange biofloc-based culture tanks. Aquaculture Research, 48(3), 1194-1208. 